\title{
АНАЛІЗ СУДОВОЇ ПРАКТИКИ ТА ПРОПОЗИЦІї ДО ЗАКОНОДАВСТВА УКРАЇНИ ЩОДО ВИДІВ ДОХОДІВ, 3 ЯКИХ УТРИМУЮТЬСЯ АЛІМЕНТИ
}

Постановка проблеми. Питання визначення видів доходів, які враховуються під час визначення розміру аліментів, регулюється ст. 81 Сімейного кодексу України (далі - СК). Диспозиція ч. 1 наведеної статті СК є бланкетною, оскільки вона відсилає до іншого нормативно-правового акта, а саме до Переліку видів доходів, які враховуються при визначенні розміру аліментів на одного з подружжя, дітей, батьків, інших осіб, затвердженого постановою Кабінету Міністрів України від 26 лютого 1993 р. № 146 (далі - постанова КМУ № 146). 3 моменту ухвалення зазначеної постанови пройшло двадцять шість років, норми ї̈ є застарілими і не враховують сучасні зміни в суспільному житті. Так, у судовій практиці дискусійним є питання про нарахування аліментів з отриманих доходів із процентів за розміщення коштів на депозитних рахунках.

Аналіз останніх досліджень і публікацій. Питання щодо нарахування аліментів досліджували у своїх працях відомі українські і закордонні цивілісти, а саме: Л. Афанасьєва, І. Апопій, Н. Бахмані, М. Вербіцька, Н. Волкова, І. Жилінкова, М. Мамедова, Л. Сапейко, С. Фурса, Ю. Червоний та інші. Однак питання нарахування аліментів з отриманих доходів із процентів за розміщення коштів на депозитних рахунках ніким не досліджувалося. Отже, окреслене питання потребує грунтовного наукового осмислення.

Метою статті є аналіз питання нарахування аліментів з отриманих доходів із процентів за розміщення коштів на депозитних рахунках на основі судової практики.

Виклад основного матеріалу. Натепер сформувалися дві позиції щодо окресленого питання:

1) проценти, отримані заявником від банківського вкладу, повинні враховуватися до видів доходів, з яких утримуються аліменти, оскільки п. 19 ч. 1 постанови КМУ № 146 визначено, що утримання аліментів із працівників провадиться з усіх видів заробітку і додаткової винагороди як за основною роботою, так і за роботою за сумісництвом, зокрема й з інших видів заробітку [1];

2) види доходів, які враховуються під час обчислення суми аліментів, чітко визначені в постанові КМУ № 146 (відсотки за розміщення коштів на депозитних рахунках до переліку видів доходів, які враховуються під час визначення розміру аліментів, не входять) [2].

Якщо керуватися принципом законності, то правозастосовувачі у своїй діяльності мають дотримуватися другої позиції, що відсотки за розміщення коштів на депозитних рахунках до переліку видів доходів, які враховуються під час визначення розміру аліментів, не входять. Зі змісту постанови КМУ № 146 вбачається, 
що законодавець, коли визначає, з яких видів заробітку стягуються аліменти, розділяє джерела надходження: якщо особа отримує грошові кошти як працівник за трудовим договором - це заробіток, якщо особа не працює за трудовим договором, а отримує кошти з інших джерел (стипендія, пенсія, прибуток від підприємницької діяльності тощо) - це дохід. Наведений у постанові Кабінету Міністрів України перелік має невичерпний характер і підлягає розширеному тлумаченню. Але розширеному тлумаченню підлягає термін «заробіток», а не «дохід». Заробіток є різновидом доходу. Доходи можуть формуватися з оплати праці, підприємницької діяльності, доходів від власності, від особистого підсобного господарства й індивідуальної трудової діяльності, інших доходів (аліменти, гонорари, спадщина, благодійна допомога тощо). 3 огляду на розмаїття джерел формування доходів Кабінет Міністрів України затвердив чіткий перелік доходів, з яких проводиться утримання аліментів (доходів у вигляді відсотків за розміщення коштів на депозитних рахунках в переліку немає).

Якщо керуватися принципом верховенства права, необхідно зазначити таке. Якість закону в контексті верховенства права є одним із головних пріоритетів його забезпечення. Свропейський суд з прав людини у своїх рішеннях підкреслював, що якість закону вимагає, щоб він був доступний для даної особи і вона також могла передбачити наслідки його застосування до неї, а також закон не має суперечити принципові верховенства права. Це означає, що в національному праві має існувати засіб правового захисту від свавільного втручання з боку державних органів у права, гарантовані Конвенцією про захист прав людини і основоположних свобод. Небезпека свавілля є особливо очевидною, коли виконавча влада виконує свої функції закрито. Закон має містити досить зрозумілі й чіткі формулювання, які давали б громадянам належне уявлення стосовно обставин та умов, за якими державні органи уповноважені вдаватися до втручання у право (справа «Гавенда проти Польщі» від 14 березня 2002 р.; справа «Аманн проти Швейцарії від 16 лютого 2000 р.).

3 огляду на те, що право має йти в ногу з обставинами, що змінюються, положення Сімейного кодексу та постанови КМУ № 146 потребують термінового перегляду та внесення змін. Термін «заробіток (дохід)» у СК України є своєрідним спадком, який залишився від Кодексу про шлюб та сім'ю України від 20 червня 1969 р. Ст. 84 цього Кодексу, у якій передбачено, що види заробітку (доходу), що підлягає облікові в разі відрахування аліментів, визначаються в порядку, встановлюваному Кабінетом Міністрів України, майже ідентична ст. 81 СК України. Ототожнення заробітку та доходу з боку радянського законодавця було виправданим, адже найвагомішим джерелом доходів населення у колишньому Радянському Союзі була заробітна плата. Ї̈̈ частка в сукупному доході сімей робітників становила приблизно 80\%, а сімей колгоспників - приблизно 60\%. Другим джерелом доходів були виплати з так званих суспільних фондів споживання (найбільшою статтею соціальних трансферів у плановій економіці були пенсіі). Ще одним джерелом доходів населення були надходження від особистого підсобного господарства. Надходження від продажу продуктів сільського господарства в Радянському Союзі становили $3-6 \%$ від сукупного доходу сімей [3]. 
3 переходом до ринкової економіки ситуація в України суттєво змінилася. За даними вибіркового обстеження домогосподарств в Україні у 2018 р., наданими Державною службою статистики України, із 3 034,4 домогосподарств 3 однієї особи працюють $23,6 \%$, не працюють $76,4 \%$; із 4905,4 домогосподарств із двох осіб працюють: одна особа - 32,7\%, дві особи $-22,4 \%$, немає тих, хто працює, - 44,9\%; із 3852,5 домогосподарств із трьох осіб працюють: одна особа $-38,5 \%$, дві особи $-43,8 \%$, три особи $-5,7 \%$, немає тих, хто працює, $-12 \%$; iз 2034,8 домогосподарств із чотирьох осіб ті, хто працюють: одна особа - 34,4\%, дві особи $-42,5 \%$, три особи $-10,9 \%$, чотири особи $-2,2 \%$, немає тих, хто працює, $-10 \%$; з 1 107,8 домогосподарств із п'яти осіб та більше ті, хто працюють: одна особа $-27,7 \%$, дві особи $-34,1 \%$, три особи $-21,8 \%$, чотири особи $-6 \%$, п’ять осіб і більше - 1\%, немає таких - 9,4\% [4]. Отже, трудова діяльність уже не є основним джерелом доходів громадян України.

За офіційними даними, доходи сучасних домогосподарств формуються завдяки: оплаті праці, прибутку та змішаним доходам, доходам від власності, соціальній допомозі й іншим одержаним поточним трансфертам. За неофіційними даними, суттєву частину доходів сучасних домогосподарств становить тіньова економіка та доходи, отримані від злочинної діяльності. Факт наявності нелегальних доходів визнаний на державному рівні. Про це свідчить ст. 164 ПК України, згідно з якою кошти або майно, отримані платником податку як хабар, викрадені чи знайдені як скарб, не зданий державі згідно із законом, належать до бази оподаткування доходів фізичних осіб. Перелік доходів фізичних осіб, що підлягають оподаткуванню, за ст. 164 ПК України досить широкий. Серед них, наприклад, є доходи у вигляді виграшів, призів, вартості успадкованого чи отриманого в дарунок майна, доходи у вигляді неустойки (штрафи, пеня), компенсування матеріальної або немайнової (моральної) шкоди тощо. Суди під час вирішення справ про стягнення аліментів виходять із того, що у ПК України міститься загальне визначення доходу для цілей оподаткування, а не в розумінні того доходу, з якого стягуються аліментні платежі [5]. Постає питання, чи відповідає соціальній справедливості позиція держави, згідно з якою перелік доходів, які підлягають оподаткуванню, набагато ширший, ніж перелік доходів, з яких стягуються аліменти?

Ратифікацією Конвенції про права дитини (далі - Конвенція) Україна взяла на себе обов’язок у всіх діях щодо дітей, незалежно від того, здійснюються вони державними чи приватними установами, що опікуються питаннями соціального забезпечення, судами, адміністративними чи законодавчими органами, приділяти першочергову увагу якнайкращому забезпеченню інтересів дитини (ч. 1 ст. 3 Конвенції). Держави - учасниці Конвенції зобов’язалися забезпечити дитині такий захист і піклування, які необхідні для їі благополуччя, беручи до уваги права й обов’язки її батьків, опікунів чи інших осіб, які відповідають за неї за законом, i із цією метою вживають усіх відповідних законодавчих і адміністративних заходів (ч. 2 ст. 3 Конвенції). 3 метою виконання міжнародних зобов'язань Україна має створити законодавчу базу щодо стягнення аліментів на одного з подружжя, дітей, батьків та інших осіб, яка відповідала б потребам сучасного суспільства та досягненням сучасної юридичної науки. 
З огляду на наявність різних джерел доходів населення України, ототожнювати поняття «заробіток» і «дохід» у сімейному законодавстві некоректно. Терміном «заробіток» можна об'єднати доходи у вигляді плати, яку особа отримує за виконану роботу. Водночас варто розуміти, що поняття «заробіток» за змістом ширше, ніж поняття «заробітна плата». Відповідно до ст. 1 Закону України «Про оплату праці», заробітна плата - це винагорода, обчислена зазвичай у грошовому виразі, яку за трудовим договором роботодавець виплачує працівникові за виконану ним роботу. Плату за виконану роботу особа може отримувати не тільки за трудовим договором, але й за цивільно-правовим договором.

Згідно з п. 16 ч. 1 постанови КМУ № 146, доходи від підприємницької діяльності, селянських (фермерських) господарств, кооперативів, об'єднань громадян, а також доходи, що припадають на частку платника аліментів від присадибної ділянки або підсобного господарства, належать до доходів, які враховуються під час визначення розміру аліментів. Зазначений пункт не відповідає основам здійснення підприємницької діяльності. За ч. 1 ст. 42 Господарського кодексу України підприємництво - це самостійна, ініціативна, систематична, на власний ризик господарська діяльність, що здійснюється суб'єктами господарювання (підприємцями) з метою досягнення економічних і соціальних результатів та одержання прибутку. У Національному положенні (стандарті) бухгалтерського обліку 1 «Загальні вимоги до фінансової звітності» надане таке визначення прибутку: прибуток сума, на яку доходи перевищують пов'язані з ними витрати. За ст. 44 Господарського кодексу України підприємництво здійснюється на основі вільного розпорядження прибутком, що залишається в підприємця після сплати податків, зборів та інших платежів, передбачених законом. 3 метою збалансованості інтересів усіх суб’єктів правових відносин утримання аліментів з осіб, що займаються підприємницькою діяльністю, селянських (фермерських) господарств, кооперативів, об’єднань громадян, а також осіб, що займаються підсобним господарством, має відбуватися не з доходу, а із прибутку після сплати ними податків, зборів та інших платежів, передбачених законом.

Згідно 3 п. 17 ч. 1 постанови КМУ № 146, утримання аліментів здійснюється з усіх видів заробітку, одержуваного адвокатами за роботу в юридичних консультаціях. Термінологічні звороти цього пункту не відповідають чинному законодавству. За ч. 3 ст. 4 Закону України «Про адвокатуру та адвокатську діяльність» адвокат може здійснювати адвокатську діяльність індивідуально або в організаційно-правових формах адвокатського бюро чи адвокатського об'єднання. Адвокат, який здійснює адвокатську діяльність індивідуально, є самозайнятою особою, яка проводить незалежну професійну діяльність. Незалежна професійна діяльність - участь фізичної особи в науковій, літературній, артистичній, художній, освітній або викладацькій діяльності, діяльність лікарів, приватних нотаріусів, приватних виконавців, адвокатів, арбітражних керівників (розпорядники майна, керуючі санацією, ліквідатори), аудиторів, бухгалтерів, оцінщиків, інженерів чи архітекторів, особи, зайнятої релігійною (місіонерською) діяльністю, іншою подібною діяльністю за умови, що така особа не є працівником або фізичною особою підприємцем та використовує найману працю не більш як чотирьох фізичних осіб 
(пп. 14.1.226 п. 14.1 ст. 14 ПК України). За ст. 178 ПК України фізичні особи, які провадять незалежну професійну діяльність, зобов'язані вести облік доходів і витрат від такої діяльності. Оподатковуваним доходом таких осіб уважається сукупний чистий дохід, тобто різниця між доходом і документально підтвердженими витратами, необхідними для провадження певного виду незалежної професійної діяльності. Заробіток, який отримує адвокат, згідно зі ст. 30 Закону України «Про адвокатуру та адвокатську діяльність», називається гонораром. Утримання аліментів потрібно здійснювати не з гонорару (заробіток), а із чистого доходу, після сплати податків, зборів та інших платежів, передбачених законом. Окрім адвокатів, за законодавством України незалежною професійною діяльністю займаються інші особи. Утримання аліментів із таких осіб має відбуватися в тому ж порядку, що і з адвокатів, що здійснюють адвокатську діяльність індивідуально.

Згідно з п. 18 ч. 1 постанови КМУ № 146, аліменти утримуються із плати, отриманої за передачу в оренду земельної ділянки або земельної частки (пай). Зазначений пункт ураховує не всі доходи, які особа отримує від власності. За ч. 3 Методичних вказівок щодо складання рахунку розподілу первинного доходу, затверджених наказом Держкомстату від 8 листопада 2004 р. № 609, доходи від власності - це первинні доходи, які одержують власники фінансових активів і матеріальних невироблених активів (земля, запаси корисних копалин тощо) від надання їх у користування іншим інституційним одиницям. Вони включають: проценти, дивіденди й аналогічні доходи, які одержують власники фінансових активів; ренту, яку одержують власники землі, надр та інших матеріальних невироблених активів від здачі їх в оренду іншим інституційним одиницям. У ст. 164 ПК України передбачені такі види доходів від власності, які можна враховувати під час визначення розміру аліментів: доходи від продажу об’єктів майнових і немайнових прав, зокрема інтелектуальної (промислової) власності, та прирівняні до них права, доходи у вигляді сум авторської винагороди, іншої плати за надання права на користування або розпорядження іншим особам нематеріальним активом (твори науки, мистецтва, літератури або інші нематеріальні активи); дохід від надання майна в лізинг, оренду або суборенду (строкове володіння та/або користування); дохід у вигляді дивідендів, відсотків за розміщення коштів на депозитних рахунках у банках та кредитних організаціях; інвестиційний прибуток від проведення операцій із цінними паперами, деривативами та корпоративними правами, випущеними в інших, ніж цінні папери, формах.

Види соціальної допомоги, перелічені в Переліку, затвердженому постановою КМУ № 146, можна залишити без змін. До вказаного Переліку не можна включати доходи від тіньової економіки й іншої протиправної діяльності. I хоча законодавець включив до бази оподаткування кошти або майно, отримані платником податку як хабар, викрадені чи знайдені як скарб, не зданий державі згідно із законом (ст. 164 ПК України), зазначені кошти та майно за ст. ст. 96-1, 96-2 Кримінального кодексу України підлягають примусовому безоплатному вилученню у власність держави.

У Переліку, затвердженому постановою КМУ № 146, перелічені доходи, з яких утримання аліментів не провадиться. Уважаємо, що перелік зазначених доходів 
можна розширити такими доходами, як: суми компенсування шкоди, завданої життю та здоров'ю особи, суми компенсування моральної шкоди; суми відшкодування втрат, яких особа зазнала у зв'язку зі знищенням або пошкодженням речі, а також витрат, які особа зробила або мусить зробити для відновлення свого порушеного права; доходів у вигляді вартості успадкованого чи отриманого в дарунок майна; доходів від відчуження майна, яке є власністю особи. Суми компенсування матеріальної або немайнової (моральної) шкоди, які отримує особа, мають компенсаційний характер і спрямовані на відновлення порушених особистих прав, свобод та інтересів. Це правило не поширюється на суми відшкодування упущеної вигоди, адже упущеною вигодою є доходи, які особа могла б реально одержати за звичайних обставин, якби її право не було порушене (п. 2 ч. 2 ст. 22 Цивільного кодексу України). Суми відшкодування упущеної вигоди можна включити до переліку доходів, які враховуються під час визначення розміру аліментів. Доходи у вигляді вартості успадкованого чи отриманого в дарунок майна, а також доходи від відчуження майна, яке є власністю особи, недоцільно включати до переліку доходів, які враховуються під час визначення розміру аліментів, через те, що зазначені доходи отримуються в результаті реалізації права власності, яке є правом особи на річ (майно), яке вона здійснює відповідно до закону за своєю волею, незалежно від волі інших осіб (ст. 316 Цивільного кодексу України).

Недоцільність включення до Переліку, затвердженому постановою КМУ № 146, доходів у вигляді вартості успадкованого чи отриманого в дарунок майна, а також доходи від відчуження майна, яке є власністю особи, не означає, що майно не може бути об'єктом стягнення. Необхідно розрізняти правовідносини, які виникають у зв'язку зі стягненням аліментів, і правовідносини, які виникають у зв'язку із заборгованістю зі сплати аліментів. Заборгованість зі сплати аліментів може утворитися тільки після набрання чинності рішенням суду про стягнення аліментів або укладення договору між сторонами про сплату аліментів, коли фактично сплата аліментів за вказаними документами не здійснювалася. Відповідно до ч. 2 ст. 71 Закону України «Про виконавче провадження», за наявності заборгованості зі сплати аліментів, сукупний розмір якої перевищує суму платежів за три місяці, стягнення може бути звернено на майно боржника. Звернення стягнення на заробітну плату не перешкоджає зверненню стягнення на майно боржника, якщо існує непогашена заборгованість щодо сплати аліментів, сукупний розмір якої перевищує суму платежів за три місяці.

Висновки. На підставі викладеного вважаємо доцільним в ч. 1 ст. 80, назві та ч. ч. $1,2,5$ ст. 183 , ч. 1 ст. 200 , ч. 1 ст. 272 СК України замість словосполучення «заробітку (доходу)» використовувати словосполучення «заробітку, прибутку від підприємницької діяльності, селянських (фермерських) господарств, кооперативів, об’єднань громадян, а також осіб, що займаються підсобним господарством, доходу від незалежної професійної діяльності, доходу від власності, суми відшкодування упущеної вигоди, соціальної допомоги» .

Перелік видів доходів, які враховуються під час визначення розміру аліментів на одного з подружжя, дітей, батьків, інших осіб, який затверджується Кабінетом Міністрів України, має включати такі види доходів: 
1) усі види заробітку і додаткової винагороди як за трудовим договором (основною роботою та роботою за сумісництвом), так і за цивільно-правовим договором:

а) заробітну плату, нараховану (виплачена) відповідно до умов трудового договору (контракту);

б) усі види доплат і надбавок до заробітної плати;

в) грошові і натуральні премії;

г) оплати за надурочну роботу, за роботу у святкові, неробочі та вихідні дні;

г) заробітну плату, що зберігається під час відпустки, а також з одержуваної в разі звільнення компенсації за невикористану протягом кількох років відпустку;

д) заробітну плату, що зберігається під час виконання державних і громадських обов'язків, та в інших випадках збереження середньої заробітної плати;

е) винагороди за загальні річні підсумки роботи підприємств і організацій;

є) одноразові винагороди (відсоткові надбавки) за вислугу років;

ж) суми винагород та інших виплат, нарахованих (виплачених) відповідно до умов цивільно-правового договору;

2) прибуток від підприємницької діяльністю, селянських (фермерських) господарств, кооперативів, об'єднань громадян, а також осіб, що займаються підсобним господарством, після сплати ними податків, зборів та інших платежів, передбачених законом;

3) чистий дохід від незалежної професійної діяльності, після сплати податків, зборів та інших платежів, передбачених законом;

4) дохід від власності:

а) дохід від продажу об'єктів майнових і немайнових прав, зокрема інтелектуальної (промислової) власності, та прирівняні до них права, дохід у вигляді сум авторської винагороди, іншої плати за надання права на користування або розпорядження іншим особам нематеріальним активом (твори науки, мистецтва, літератури або інші нематеріальні активи);

б) дохід від надання майна в лізинг, оренду або суборенду (строкове володіння та/або користування);

в) дохід у вигляді дивідендів, відсотків за розміщення коштів на депозитних рахунках у банках та кредитних організаціях;

г) інвестиційний прибуток від проведення операцій із цінними паперами, деривативами та корпоративними правами, випущеними в інших, ніж цінні папери, формах;

5) суму відшкодування упущеної вигоди - доходу, який особа могла б реально одержати за звичайних обставин, якби її право не було порушено;

6) соціальну допомогу:

а) одержувані пенсії, за винятком надбавок до пенсії, що виплачуються особам з інвалідністю першої групи на догляд за ними;

б) допомогу 3 державного соціального страхування, а також допомогу через тимчасову непрацездатність, крім допомоги з догляду за хворою дитиною віком до 14 років;

в) доплати до допомоги з державного соціального страхування, що виплачуються коштом підприємств, установ, організацій; 
г) суми, виплачуваних для відшкодування збитків у зв’язку з утратою працездатності внаслідок каліцтва або іншого пошкодження здоров'я, за винятком сум для відшкодування витрат на догляд за ними, на додаткове харчування, санаторно-курортне лікування (зокрема, оплата проїзду) і протезування потерпілих;

г) допомогу з безробіття;

д) державну соціальну допомогу особам з інвалідністю з дитинства, призначену відповідно до Закону України «Про державну соціальну допомогу особам з інвалідністю з дитинства та дітям з інвалідністю»;

е) стипендії, що виплачуються студентам у період навчання у вищих навчальних закладах, учням професійних навчально-виховних закладів та слухачам навчальних закладів підвищення кваліфікації та перепідготовки кадрів.

\section{Jimepamypa}

1. Ухвала у справі № 760/4569/18 від 29 березня 2018 р. Солом'янського районного суду міста Києва. URL: http://www.reyestr.court.gov.ua/Review/73501999 (дата звернення: 12.03.2020).

2. Постанова у справі № 760/4569/18 від 5 вересня 2018 р. Апеляційного суду міста. URL: http://www.reyestr.court.gov.ua/Review/76302715 (дата звернення: 12.03.2020).

3. Сенів Л. Особливості джерел доходів населення України. Вісник Національного університету «Львівська політехніка». 2011. № 720. С. 444-445.

4. Соціально-демографічні характеристики домогосподарств України у 2018 р. (за даними вибіркового обстеження умов життя домогосподарств України) : статистичний збірник / Державна служба статистики України. С. 26, 86. URL: https://ukrstat.org/en/druk/publicat/kat_u/2018/zb/07/ zb_sdhdu2018pdf.pdf (дата звернення: 12.03.2020).

5. Постанова у справі № 640/537/14-ц від 7 травня 2018 р. / Верховний Суд. URL: http://www.reyestr.court.gov.ua/Review/73837478 (дата звернення: 13.03.2020).

\section{Анотація}

Коломієць Ю. Ю., Сулейманова С. Р. Аналіз судової практики та пропозиції до законодавства України щодо видів доходів, з яких утримуються аліменти. - Стаття.

У статті проаналізовано проблемні питання щодо визначення видів доходів, які враховуються під час утримання аліментів на основі прецедентної практики та наукових досліджень. Так, у судовій практиці дискусійним є питання про нарахування аліментів з отриманих доходів із процентів за розміщення коштів на депозитних рахунках. Натепер сформувалися дві позиції щодо окресленого питання: 1) проценти, отримані заявником від банківського вкладу, повинні враховуватися до видів доходів, з яких утримуються аліменти, оскільки пунктом 19 частини 1 постанови Кабінету Міністрів України № 146 визначено, що утримання аліментів із працівників провадиться з усіх видів заробітку і додаткової винагороди як за основною роботою, так і за роботою за сумісництвом, зокрема з інших видів заробітку; 2) види доходів, які враховуються під час обчислення суми аліментів, чітко визначені в постанові Кабінету Міністрів України № 146 (відсотки за розміщення коштів на депозитних рахунках до переліку видів доходів, які враховуються під час визначення розміру аліментів, не входять). Отже, не всі відповіді, що виникають у судовій практиці, передбачені Переліком видів доходів, які враховуються під час визначення розміру аліментів на одного з подружжя, дітей, батьків, інших осіб, затвердженому Постановою Кабінету Міністрів України від 26 лютого 1993 року № 146. Зазначене питання висвітлюється з погляду принципу законності та верховенства права. Зважаючи на наявність різних джерел доходів населення України, ототожнювати поняття «заробіток» $\mathrm{i}$ «дохід» у сімейному законодавстві некоректно. Терміном «заробіток» можна об'єднати доходи у вигляді плати, яку особа отримує за виконану роботу. Водночас варто розуміти, що поняття «заробіток» за змістом ширше, ніж поняття «заробітна плата». Відповідно до статті 1 Закону України «Про оплату праці», заробітна плата - це винагорода, обчислена зазвичай у грошовому виразі, яку за трудовим договором роботодавець виплачує працівникові за виконану ним роботу. Плату за виконану роботу особа може отримувати не тільки за трудовим договором, але й за цивільно-правовим договором.

Стверджується, що ці проблеми деякою мірою зумовлені недосконалістю чинного законодавства, пропонуються шляхи їх подолання. На підставі викладеного пропонуеться в частині 1 статті 80, назві 
та частинах 1, 2, 5 статті 183, частині 1 статті 200, частині 1 статті 272 Сімейного кодексу України замість словосполучення «заробітку (доходу)» використовувати словосполучення «заробітку, прибутку від підприємницької діяльності, селянських (фермерських) господарств, кооперативів, об'єднань громадян, а також осіб, що займаються підсобним господарством, доходу від незалежної професійної діяльності, доходу від власності, суми відшкодування упущеної вигоди, соціальної допомоги» . Також у висновках пропонується внести зміни у Перелік видів доходів, які враховуються під час визначення розміру аліментів на одного з подружжя, дітей, батьків, інших осіб, який затверджується Кабінетом Міністрів України, і пропонується перелік відповідних видів доходів.

Ключові слова: судова практика, заробіток, дохід, аліменти, відсотки, депозитний рахунок, Верховний Суд.

\section{Summary}

Kolomiets Yu. Yu., Suleimanova S. R. Analysis of legal practice and suggestions to the legislation of Ukraine regarding the types of income from aliments. - Article.

This article analyzes the problematic issues that arise in determining the types of income that are taken into account in the formulation of alimony on the basis of case law and scientific research. Thus, not all the answers that arise in court practice are provided by the List of types of income, which are taken into account when determining the amount of alimony for one of the spouses, children, parents, other persons, approved by the Cabinet of Ministers of Ukraine of February 26, 1993 № 146. Twenty-six years have passed since the adoption of this Resolution, its norms are outdated and do not take into account modern changes in public life. Thus, in judicial practice, the issue of accrual of alimony from interest income for the placement of funds on deposit accounts is debatable. To date, two positions have been formed on this issue: 1) interest received by the applicant from the bank deposit must be taken into account in the types of income from which alimony is withheld, as paragraph 19 of part 1 of the Resolution of the Cabinet of Ministers № 146 stipulates that alimony is deducted from all types of earnings and additional remuneration part-time work, including other types of earnings; 2) types of income that are taken into account when calculating the amount of alimony, clearly defined in the Resolution of the Cabinet of Ministers № 146 (interest on the placement of funds on deposit accounts in the list of types of income that are taken into account when determining the amount of alimony is not included). Attention is being argued that the problems in question are to some extent caused by the imperfection of the current legislation and suggest ways of overcoming them. Given the existence of different sources of income for the population of Ukraine, it is incorrect to equate the concepts of "earnings" and "income" in family law. The term "earnings" can be combined into income in the form of payment that a person receives for work performed. It should be understood that the concept of "earnings" in content is broader than the concept of "wages". According to Article 1 of the Law of Ukraine "On Remuneration of Labor" wages - a remuneration, calculated, as a rule, in monetary terms, which under the employment contract the employer pays the employee for the work performed by him. A person may receive payment for work performed not only under an employment contract, but also under a civil contract. It is argued that these problems are to some extent caused by the imperfection of the current legislation and suggest ways to overcome them. Based on the above, it is proposed in Part 1 of Article 80, title and part 1, 2, 5 of Article 183, part 1 of Article 200, part 1 of Article 272 of the IC of Ukraine instead of the phrase "earnings (income)" to use the phrase "earnings, income from entrepreneurial activities, peasant (farmer) farms, cooperatives, associations of citizens, as well as persons engaged in subsidiary farming, income from independent professional activity, income from property, the amount of compensation for lost profits, social assistance". Also, the conclusions propose to amend the List of types of income that are taken into account when determining the amount of alimony for one of the spouses, children, parents, other persons, which is approved by the Cabinet of Ministers of Ukraine, and proposes a list of relevant types of income.

Ker words: judicial practice, earnings, income, alimony, interest, deposit account, Supreme Court. 